\title{
The Interrelation between Breakfast Intake with Academic Performance, Cognitive Skills and Body Mass Index (BMI) among Students UiTM Terengganu Branch, Malaysia
}

Noraida Abdul Karim, Nur Amalin Hayati Abdullah, Faliza Mahamed Ali, Zatul Iffah Mohd Fuza, Nurul Ashikin Ismail

To Link this Article: http://dx.doi.org/10.6007/IJARBSS/v11-i16/11229

DOI:10.6007/IJARBSS/v11-i16/11229

Received: 06 July 2021, Revised: 09 August 2021, Accepted: 25 August 2021

Published Online: 19 September 2021

In-Text Citation: (Karim et al., 2021)

To Cite this Article: Karim, N. A., Nur Amalin Hayati Abdullah, F. M. A., Fuza, Z. I. M., \& Ismail, N. A. (2021). The Interrelation between Breakfast Intake with Academic Performance, Cognitive Skills and Body Mass Index (BMI) among Students UiTM Terengganu Branch, Malaysia. International Journal of Academic Research in Business and Social Sciences, 11(16), 209-218.

Copyright: (C) 2021 The Author(s)

Published by Human Resource Management Academic Research Society (www.hrmars.com)

This article is published under the Creative Commons Attribution (CC BY 4.0) license. Anyone may reproduce, distribute, translate and create derivative works of this article (for both commercial and non-commercial purposes), subject to full attribution to the original publication and authors. The full terms of this license may be seen

at: http://creativecommons.org/licences/by/4.0/legalcode

Special Issue Title: Contemporary Issues in Tourism and Hospitality industry, 2021, Pg. 209 - 218

Full Terms \& Conditions of access and use can be found at http://hrmars.com/index.php/pages/detail/publication-ethics 


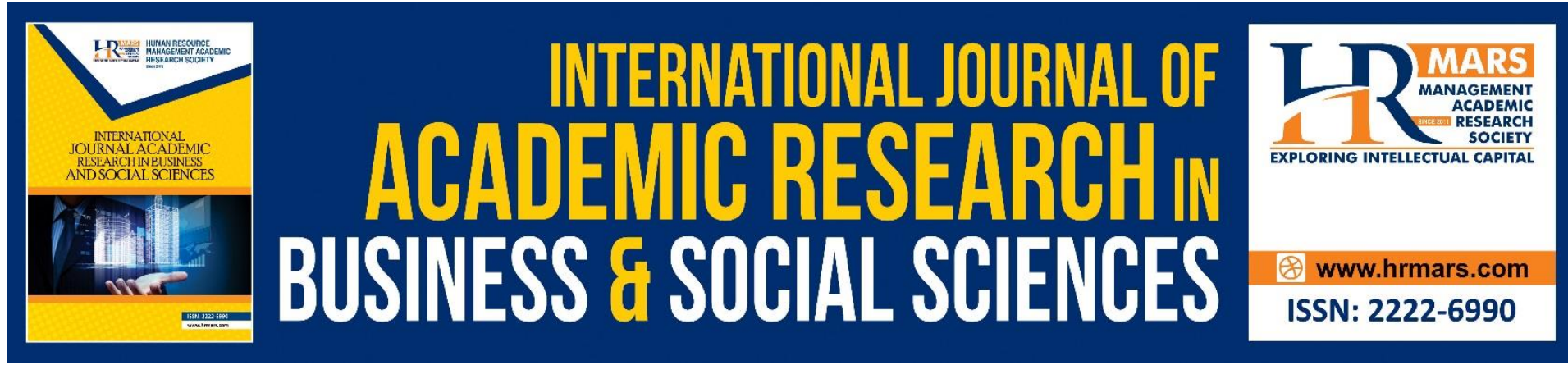

\title{
The Interrelation between Breakfast Intake with Academic Performance, Cognitive Skills and Body Mass Index (BMI) among Students UiTM Terengganu Branch, Malaysia
}

\author{
Noraida Abdul Karim¹, Nur Amalin Hayati Abdullah ${ }^{1}$, Faliza \\ Mahamed Ali ${ }^{1}$, Zatul Iffah Mohd Fuza ${ }^{1}$, Nurul Ashikin Ismail ${ }^{5}$ \\ ${ }^{1}$ Faculty of Hotel and Tourism Management, UiTM Cawangan Terengganu, Malaysia \\ ${ }^{5}$ Faculty of Science and Food Technology, Universiti Putra Malaysia, Selangor, Malaysia \\ Email: faliz719@uitm.edu.my
}

\begin{abstract}
Breakfast is the most important meal of the day as nutrient intake is crucial to energize the body and maintain a high metabolic rate at the beginning of the day. Although many breakfasts awareness programs and studies have shown the effects of skipping breakfast, most higher institution students tend to skip breakfast supposedly to decrease their body mass index (BMI). Studies have also debated that skipping breakfast affects students' academic performance due to low nutrient intake. Therefore, the study investigates the interrelation between breakfast intake and students' academic performance in Universiti Teknologi MARA (UiTM), Terengganu Branch, Dungun Campus. The findings revealed that breakfast intake significantly impacted the students' academic performance and cognitive skills. Interestingly, the study discovered that although breakfast intake energizes the body, there is no relationship between the students' breakfast intake and BMI. Hence, the study provides insight to enhance the understanding of the interrelation between breakfast intake and student performance.
\end{abstract}

Keywords: Breakfast, Academic Performance, Cognitive Skills, Body Mass Index, Malaysia

\section{Introduction}

Skipping breakfast is common in modern days due to different family lifestyles (Vishnukumarc et al., 2017). Although breakfast is considered the first important meal, some higher institution students tend to skip breakfast, assuming that it would decrease their body mass index. Contrarily, studies have shown that skipping breakfast would increase body mass index (Aarthi et al., 2018). According to Huzaini, (2015), the relationship between breakfast and body health is undeniably crucial. Furthermore, the Journal of Obesity Research revealed that 78 percent of the respondents could reduce and maintain their weight by eating breakfast regularly. 
Previous studies also highlighted that students fail to take proper breakfast due to waking up late, laziness, or losing body weight, leading to low performance and losing focus in academics (Arshad et al., 2014). Breakfast is deemed "the most important meal of the day" as the nutrient intakes at the beginning of the day are essential and needed to fuel the body for the rest of the day and help maintain a high metabolic rate (Ren et al., 2020). Significantly, breakfast consumption is also interrelated with a good diet, better nutrient intake, and better physical fitness (Zhu et al., 2019). The problem students face while studying on an empty stomach is losing focus partly due to low blood sugar (Adolphus et al., 2013). Recent epidemiological studies show that skipping breakfast in the long term could increase the risk of depressive symptoms (Ren et al., 2020). A study reported that going to school without breakfast caused laziness, lack of attention and behavioral problems among students; thus, lowering educational performance (Arshad et al., 2014). Therefore, a continuous energy supply from glucose intake is needed to maintain the high metabolic rate and increase focus in academic learning.

The students tend to consume adequate nutrient intake and dietary fibre and lower total fat and cholesterol if they continuously consume breakfast before starting the day (Sampson et al., 1995). Moreover, students who eat breakfast can enhance memory, concentration, and academic performance compared to those who skip breakfast (Pollitt et al., 1983; Vaisman et al., 1996; Wesnes et al., 2003). Unfortunately, there is a lack of focus on the topic, although having breakfast affects academic performance. Therefore, the study investigates the interrelation between breakfast intake and student performance in terms of academic performance, cognitive skills and body mass index (BMI).

\section{Literature Review}

\section{Breakfast Intake}

Countless food varieties have been produced by inventors, with the main focus on healthy meals. Although a healthy lifestyle is crucial for all individuals, not all practice it. Accordingly, a healthy lifestyle entails taking breakfast as it is the most important meal of the day. Huzaini, (2015) reported in the Journal of Obesity Research that approximately 78 percent of the respondents lost weight by eating breakfast frequently. Furthermore, many breakfast awareness programs such as Milo Malaysia Breakfast Program have been conducted in Malaysia, including free breakfast to attract the public to participate in breakfast awareness programs. When being asked by the

President of the Malaysian Chinese Association, Wee Ka Siong, about the legitimacy of the school's free breakfast program, Dr Maszlee (previous Minister of Education) stated that the children must be taken care of with balanced nutrition to ensure they stay healthy and active daily (Bernama, 2019). Nestle Malaysia, Singapore and Brunei Regional Head, Alois Hofbauer concerning the Milo Malaysia Breakfast Program, aimed to highlight the importance of breakfast awareness among citizens and increase the parents' awareness to ensure their children are educated on regular breakfast intake (Lai \& Soo, 2013).

Breakfast intake and breakfast skipping have two different effects on the students' class performance. For instance, students who eat breakfast before starting the day with ongoing work and lessons are energetic throughout the day as the breakfast has high nutrients to last the entire day. In contrast, those who frequently skip breakfast experience impacts on class 
and body performances. Therefore, breakfast provides an essential nutritional need in the body and must be taken as it is the most important meal of the day (Arshad et al., 2014) and affects body performance and health. Zainab and Ayesha (2017) stated that breakfast is continually considered the most important meal of the day for body performance associated with the healthy intake of nutrients, BMI and lifestyles.

Generally, some people always have breakfast as the first meal while others skip it altogether. Skipping breakfast has become the norm in modern days due to family lifestyle differences (Vishnukumar et al., 2017). Previous studies have shown that students do not take proper breakfast due to waking up late, laziness, or losing weight, which lowers performance and alertness in academic settings (Arshad et al., 2014). Students do not realize the importance of breakfast as most of them tend to skip breakfast due to waking up late, losing weight, or losing appetite in the morning. Students should realize that breakfast is essential, especially in their daily diet. Therefore, the students need to consider having or skipping breakfast because both can impact their performances.

\section{Academic Performance}

The Cambridge dictionary defined performance as how good or how well a person works; hence, academic performance is how well a person or a student performs academically. Work done by a person can be influenced by the energy content in the body, which becomes futile without enough glucose for energy. Hence, breakfast is a crucial meal and dietary source for energy during the day. For instance, many researchers found that breakfast is essential as it provides crucial nutritional needs for the body (Arshad et al., 2014). Moreover, breakfast intake can influence students in numerous ways, such as completing the task given by lecturers or giving total concentration during the lessons. Several studies further highlighted that one factor influencing academic performance is health and nutrition intake; thus, breakfast is essential for students since it provides crucial nutritional needs for the body (Zainab \& Ayesha, 2017).

Zainab and Ayesha (2017) added that breakfast intake creates a positive short-term effect on the students' intellectual and cognitive performance. Nonetheless, taking breakfast may impact

individuals differently based on their body and health. Based on the findings, breakfast intake is one factor that impacts the students' academic performance. Furthermore, Arshad et al. (2014) found a significant relationship between breakfast intake and student performance in class whereby the students feel extra lazy and become inactive during the learning process from low nutritional intake, not fully participating and concentrating in class. These unfavorable behaviors in class could lead to low academic performance; thus, breakfast intake is very important to start the day with gaining knowledge and lessons besides doing other activities.

\section{Cognitive Skills}

Besides academic performance, lacking breakfast intake affects students' ability to perform tasks such as focusing in class and less participation during Question and Answer (Q\&A) sessions (Rueckert \& Graftman, 1996; Wilkins et al., 1987). Research has proven that breakfast intake has adequate nutrients crucial for the body that provide enough nutrients 
for one person to perform tasks during the day (Bhattacharya et al., 2006). Meanwhile, Wesnes et al. (2003) discussed the limitation in encouraging attention and recalling memory as impacts of short-term hunger, causing students to have issues in solving riddles and mathematical problems in school. Furthermore, Pollitt et al. (1982a, 1983b) discovered that skipping breakfast produced unwanted effects on the ability to do tasks and on the students' overall performance in class. Breakfast is needed to jump-start metabolism, being the first meal of the day fed into the body after resting for 12 hours at night. Numerous studies conducted on the importance of breakfast have proven that people who eat this meal have a higher level of resting metabolism. Additionally, students who consume breakfast less likely experience mental stress and tend to get good grades and better school attendance (Sun et al., 2013). In contrast, the students who skip breakfast experience a negative adverse effect on cognition, psychosocial function, school attendance, and mood (Sun et al., 2013).

Chung et al. (2015) found that those who skip breakfast have relatively less intake of various minerals and vitamins and lower total energy intake than people who take breakfast (Chung et al., 2015). Nutrient intake from the rest of the day does not compensate for the missed nutrients from skipping breakfast (Fayet-Moore et al., 2016). Generally, fatigue is a common problem among students in higher institutions related to dietary habits such as skipping breakfast, and the hunger in the morning could be why students have poor ability to do the tasks in class (Adolphus et al., 2013).

\section{Body Performance}

Past studies have proven that students with low social and economic status, low parental educational level and serious family issues tend to be the ones to skip breakfast (Zainab \& Ayesha, 2017). Zainab and Ayesha (2017) mentioned that breakfast is continually deemed the most important meal of the day for the body's performance as it is associated with healthy intake of nutrients, Body Mass Index (BMI) and lifestyles. Nonetheless, studies found that the main reason behind breakfast skipping is students not having enough time in the morning due to waking up late; no appetite to eat in the morning, and being concerned about body weight and body image. A study revealed that breakfast intake is not completely associated with body mass index (BMI) but more with body fat

percentage (Najwa \& Appukutty, 2018). Moreover, recent studies discovered that students who lack nourishment tend to skip school often and face more health problems than wellnourished students (Zainab \& Ayesha, 2017). Significantly, recent studies revealed that people who skip breakfast tend to be overweight than those who do not skip breakfast (Vishnukumar et al., 2017), observing high intake of miscellaneous food such as junk food high in saturated fat among those who skip breakfast. Hence, those who skip breakfast tend to have an unhealthy body due to a lack of good nourishment to start the day.

Students who do not consume breakfast tend to be less physically active and have low cardiorespiratory fitness level (Sandercock et al., 2010). Moreover, several studies have reported that children and adolescents who habitually consume breakfast have a reduced chance of being overweight (Szajewska \& Ruszczynski, 2010; Hunty et al., 2013). Ostachowska-Gasiorc et al (2016) stated that adolescence is an intense physical period and psychosocial development requiring a balanced diet. Although there is a high prevalence of breakfast skipping at the age of 25 years old and below, the trend decreases with the increase 
in age (Sakurai, \& Montero-Odasso, 2017). A study highlighted that frequently skipping breakfast may result in health problems as there is an increase in the risk of heart disease (Timlin \& Pereira, 2007).

\section{Methodology}

A quantitative method was applied to achieve the research objectives. Based on the Student Affairs and Academic Affairs Department of Dungun, Kuala Terengganu and Bukit Besi campuses (2019), there are 4,911 students in the UiTM Terengganu branch. The study used standard formula sample measurement with $95 \%$ confidence level and $0.05 \%$ error and collected 357 out of the 4,911 samples. The study also used the convenient sampling method to determine the sample population. Next, questionnaires were distributed through online surveys by using the student club comprising the D'hoteliers club. The questionnaires were divided into three sections: demographic section, breakfast intake and impact of breakfast on student performance.

Before the actual survey, a pilot test was conducted on 30 volunteer students through an online survey to avoid any wording error and determine the reliability of the questionnaires. Besides, the pilot test ensured the meaning of the questionnaires was portrayed well with the same meaning to all respondents. All comments by lecturers were compiled and the changes to the questionnaire such as rewording, adding and eliminating questions were done based on the comments. The table below shows the reliability test results for the questionnaires, whereby the Cronbach's Alpha for the reliability test was 0.810 . According to the rule of thumb for interpreting the questionnaires, the range of 0.9 - 0.8 of Cronbach's Alpha means that the questionnaires are good and acceptable.

Table 1: Reliability Test

\begin{tabular}{|l|l|l|}
\hline $\begin{array}{l}\text { Cronbach's } \\
\text { Alpha }\end{array}$ & $\begin{array}{l}\text { Cronbach's } \\
\text { Alpha Based } \\
\text { on } \\
\text { Standardized } \\
\text { Items }\end{array}$ & N of Items \\
\hline .810 & .747 & 12 \\
\hline
\end{tabular}

From the 357 respondents, the data collection amounted to only 258 total respondents. However, according to Earl Babbie (1990), a response rate of $70 \%$ is considered very good. Thus, 258 out of 357 response rate is acceptable as it is $72.2 \%$ of the overall response rate. Additionally, the study applied descriptive and inferential statistics to analyze the data.

\section{Result and Discussion}

Table 2 shows that most questionnaires were answered by female students at the diploma level with good results (CGPA) from 3.00 - 3.49. The lowest number of respondents comprised male students at the degree level. The majority of UiTM students majoring in diploma explains why degree students were less than diploma students. As for the Body Mass Index (BMI) of the students, most of them are at normal weight, although there are those in the range of underweight (15.1\%), overweight (20.5\%), and obese (11.2\%). 
Table 2: Demographic

\begin{tabular}{|l|l|l|}
\hline Demographic & Item & Percentage \\
\hline Gender & Male & $22.5 \%$ \\
& Female & $77.5 \%$ \\
\hline Educational level & Diploma & $60.9 \%$ \\
& Degree & $39.1 \%$ \\
\hline CGPA & 2.49 and below & $8.9 \%$ \\
& $2.50-2.99$ & $15.1 \%$ \\
& $3.00-3.49$ & $39.1 \%$ \\
& 3.49 and above & $36.8 \%$ \\
\hline Body mass index & Underweight (18.4 and below) & $15.1 \%$ \\
(BMI) & Normal (18.5 - 24.9) & $53.1 \%$ \\
& Overweight (25 - 29.9) & $20.5 \%$ \\
& Obesity (30 and above) & $11.2 \%$ \\
\hline
\end{tabular}

For breakfast intake, the findings showed that $53.9 \%$ of the respondents do not usually eat breakfast, but it does not mean that most of them never had breakfast since the second question showed that $55.8 \%$ of respondents eat breakfast on the day of the questionnaires. Additionally, the

third question showed that most respondents never had breakfast even though they always skip breakfast. Thus, most respondents take breakfast as the first meal, and few do not eat breakfast. As for the level of awareness about breakfast, many respondents demonstrated awareness of the importance of breakfast. The impact on student performance revealed that most respondents slightly agree (30.6\%) about the reasons for skipping breakfast. Regarding the body performance when taking breakfast, most respondents completely agree on being healthy and more energetic if they take breakfast, while most agree on feeling tired if they skip breakfast. A similar study by Ren et al. (2020) noted that consistently having breakfast could protect against depressive symptoms. For cognitive aspects, the findings showed that most students agreed with the facts that by having breakfast, they are more focused in class, active and generate ideas during group discussion. Thus, the chi-square test was conducted to determine the relationship between breakfast intake and all the variables (academic performances, cognitive skills and body performances). The survey involves the 'yes or no' question for breakfast intake, which requires classifying the data into distinct categories and a five-point Likert scale for the impact. Therefore, the chi-square test is the most suitable test to determine whether there is evidence of an association between each category.

Table 3: Pearson Chi Square Result

\begin{tabular}{|l|l|l|l|l|}
\hline \multirow{2}{*}{ Variables } & \multicolumn{3}{|l|}{ Pearson Chi Square Test } & \multirow{2}{*}{ Relationship } \\
\cline { 2 - 4 } & Value & df & Asym. Sig (2-sided) & \\
\hline $\begin{array}{l}\text { Breakfast intake ?Academic } \\
\text { Performance }\end{array}$ & $8.168^{\mathrm{a}}$ & 3 & .043 & Significance \\
\hline Breakfast intake ? Cognitive Skills & $22.398^{\mathrm{a}}$ & 4 & .000 & Significance \\
\hline $\begin{array}{l}\text { Breakfast intake ? Body Mass Index } \\
\text { (BMI) }\end{array}$ & $1.220^{\mathrm{a}}$ & 3 & .748 & Not Significance \\
\hline
\end{tabular}


Table 3 above reveals the chi-square test performed between breakfast and academic performance (their current grade per average (CGPA)). Since the $p$-value is lower than the significance (alpha) level (0.05), there is a relationship between breakfast intake and students' CGPA. In other words, the two variables are dependent on each other, as confirmed by Zainab \& Ayesha (2017), whereby one of the factors influencing academic performance is health and nutrition intake. Notably, breakfast is essential for students since it provides important nutritional needs in the body. For the breakfast intake and cognitive skills, the p-value of the test is below the significance (alpha) level, which is 0.05 . Therefore, there is a relationship between breakfast intake and students' cognitive skills such as their concentration and participation in class.

Students who consume breakfast are less likely to experience mental stress and tend to achieve better school attendance (Sun et al., 2013). Nonetheless, Table 3 above shows no relationship between breakfast intake and $\mathrm{BMI}$ as the $\mathrm{p}$-value is more than the alpha or significance level. Hence, breakfast intake and $\mathrm{BMI}$ are independent variables. As mentioned before, breakfast consumption is not the main reason that contributes to all of the impacts. Furthermore, Glovannini et al. (2010) stated that the effects of skipping breakfast are not entirely due to missing breakfast. Thus, it is acceptable that BMI is not affected by breakfast intake.

\section{Conclusion}

Breakfast consumption is one of the reasons that contribute to students' academic performance, cognitive skills and body performance. Nevertheless, other reasons such as waking up late or lack of sleep may also contribute to those impacts. The research objectives are achieved based on the survey findings. Although the results obtained were beyond the researcher's expectation, the research questions were based on (a)whether the students are aware of the importance of breakfast intake and (b)whether there is a relationship between breakfast intake and student performance. In conclusion, the study found that most UiTM Terengganu Branch, Dungun Campus students were aware of the importance of breakfast and how breakfast intake can affect academic performance and cognitive skills. Additionally, the study also found that students' BMI was not affected by breakfast consumption. A nutritious breakfast should contain more fiber and protein, less sugar and fat, and be high in vitamin $A$, vitamin $B$, and minerals, all of which are beneficial to one's health. Because of the importance of breakfast, it was included in a variety of educational programmes. Breakfast consumption necessitates greater awareness among the students as well as adults (Rani et al., 2021).

Future researchers should cover the deficiencies and produce accurate results regarding breakfast. Furthermore, future researchers should provide suggestions to reduce breakfast skipping among students and people in general. In order to get more accurate results, the sample size should be widened and not limited to the Dungun area only. Besides, researchers should investigate previous and current grade students to acquire more accurate results on academic performances. In the future, researchers should widen the limitations on body performance instead of focusing only on BMI. They should also study the respondent's body image, weight, size and body fat. Discovering any information that other researchers could not focus on could help future researchers determine the accurate results of the research objectives. 


\section{Corresponding Author}

Faliza Mahamed Ali

Faculty of Hotel and Tourism Management, UiTM Cawangan Terengganu, Kampus Dungun. Email: faliz719@uitm.edu.my

\section{References}

Adolphus, K., Lawton, C. L., \& Dye, L. (2013). The effects of breakfast on behavior and academic performance in children and adolescents. Frontiers in Human Neuroscience, 7, 425.

Arshad, N., Ahmed, U., Yasin, G., Manj, Y. N., \& Umair, A. (2014). Impacts of Food Intake Pattern on Education Performance of University Students. Pakistan Journal of Nutrition, 13(12), 746-751.

Bhattacharya, J., Currie, J., \& Haider, S. (2006). Breakfast of Champions? The School Breakfast Program and The Nutrition of Children and Families. Journal of Human Resources, 41, $445-446$.

Bernama. (2019). Program sarapan pagi bermula 20 Jan di 100 sekolah. Malaysia Kini. Publish on 27 December 2019. Retrieved on 15 June 2021 from https://www.malaysiakini.com/news/505102

Hunty, A., Gibson, S., \& Ashwell, M. (2013). Does regular breakfast cereal consumption help children and adolescents stay slimmer? A systematic review and meta-analysis. Obesity Facts, 6(1), 70-85.

Fayet-Moore, F., Kim, J., Sritharan, N., \& Petocz, P. (2016). Impact of breakfast skipping and breakfast choice on the nutrient intake and body mass index of Australian children. Nutrients, 8(8), 487.

Glovannini, M., Agostoni, C., \& Shamir, R. (2010). Symposium Overview: Do We All Eat Breakfast and It Is Important? Critical Reviews in Food Science \& Nutrition, 50(2), 97 99.

Huzaini, N. B. (2015). Kepentingan Sarapan Pagi. Berita Harian Online. Publish on July 18, 2015. Berita Harian Online. Retrieve on 3 Jun 2021 from https://www.bharian.com.my/bhplus-old/2015/07/68630/kepentingan-sarapan-pagi

Lai, W., \& Soo, S. (2013). Malaysians energized on Malaysia Breakfast Day with MILO. Nestle. Retrieved on 15 June 2021 from https://www.nestle.com.my/media/pressreleases/allpressreleases/2013_malaysians_ energized_on_mbd

Arsyad, N., Ahmed, U. (2014). Impact of Breakfast Habits on Education Performance of University Students. International Journal of Academic Research in Progressive Education and Development, 3(1).

Najwa, N. R., \& Appukutty, M. (2018). Breakfast consumption association with body status and physical activity among female university students. Malaysian Journal of Movement, Health \& Exercise, 7(2), 93 - 106.

Ostachowska-Gasior, A., Piwowar, M., Kwiatkowski, J., Kasperczyk, J., \& Skop-Lewandowska, A. (2016). Breakfast and other meal consumption in adolescents from Southern Poland. International Journal of Environmental Research and Public Health, 13(5), 453.

Pollitt, E., Lewis, N. L., Garza, C., \& Shulman, R. J. (1983). Fasting and cognitive function. J. Psychiatr. Res, 17,169-74.

Rani, R., Dharaiya, C. N., \& Singh, B. (2021). Importance of not skipping breakfast: a review. International Journal of Food Science \& Technology, 56(1), 28-38. 
Ren, Z., Cao, J., Cheng, P., Shi, D., Cao, B., Yang, G., \& Peng, L. (2020). Association between breakfast consumption and depressive symptoms among Chinese college students: a cross-sectional and prospective cohort study. International Journal of Environmental Research and Public Health, 17(5), 1571.

Rueckert, L., \& Grafman, J. (1996). Sustained attention deficits in patients with right frontal lesions. Neuropsychological, 34(10), 953-963.

Sakurai, R., \& Montero-Odasso, M. (2017). Apolipoprotein E4 allele and gait performance in mild cognitive impairment: results from the gait and brain study. Journals of Gerontology Series A: Biomedical Sciences and Medical Sciences, 72(12), 1676-1682.

Sampson, A. E., Dixit, S., Meyers, A. F., \& Houser Jr, R. (1995). The nutritional impact of breakfast consumption on the diets of inner-city African-American elementary school children. Journal of the National Medical Association, 87(3), 195.

Sandercock, G. R. H., Voss, C., \& Dye, L. (2010). Associations between habitual school-day breakfast consumption, body mass index, physical activity and cardiorespiratory fitness in English schoolchildren. European Journal of Clinical Nutrition, 64(10), 1086-1092.

Sun, J., Yi, H., Liu, Z., Wu, Y., Bian, J., Wu, Y., \& Yang, Y. (2013). Factors associated with skipping breakfast among Inner Mongolia Medical students in China. BMC Public Health, 13(1), 1-8.

Sung, H. M., Chung, H. Y., Lee, S. J., Lee, J. M., Huh, S., Lee, J. W., \& Cho, B. C. (2015). Clinical experience of the Klippel-Trenaunay syndrome. Archives of Plastic Surgery, 42(5), 552.

Szajewska, H., \& Ruszczyński, M. (2010). Systematic review demonstrating that breakfast consumption influences body weight outcomes in children and adolescents in Europe. Critical Reviews in Food Science and Nutrition, 50(2), 113-119.

Timlin, M. T., \& Pereira, M. A. (2007). Breakfast frequency and quality in the etiology of adult obesity and chronic diseases. Nutrition reviews, 65(6), 268-281.

Vaisman, N., Voet, H., Akivis, A., \& Vakil, E. (1996). The effects of breakfast timing on the cognitive function of elementary school students. Arch. Pediatr. Adolesc. Med, 150, 1089-92.

Vishnukumar, S., Sujirtha, N., \& Ramesh, R. (2017). Journal for Nutrition. Journal for Nutrition, 110, 159-165.

Vishnu, S., Sujirtha, N., \& Ramesh, R. (2016). The Effect of Breakfast on Academic Performance and Behaviour in School Children from Batticola District. Journal for Nutrition.

Wilkins, A. J., Shallice, T., \& McCarthy, R. (1987). Frontal Lesions and Sustained attention. Neuropsychological, 25, 359 - 365.

Wesnes, K. A., Pincock C., Scholey A. (2012). Breakfast is Associated with Enhanced Cognitive Function in School Children. Appetite, 59, 646-649.

Wesnes, K. A., Pincock, C., Richardson, D., Helm, G. and Hails, S. (2003). Breakfast reduces declines in attention and memory over the morning in schoolchildren. Appetite, 41(3), 29-31.

Zhu, Z., Cui, Y., Gong, Q., Huang, C., Guo, F., Li, W., \& Wang, Y. (2019). Frequency of breakfast consumption is inversely associated with the risk of depressive symptoms among Chinese university students: A cross-sectional study. PloS One, 14(8), e0222014. 